\title{
Pengaruh Disiplin Kerja, Pengalaman Kerja, Kepuasan Kerja dan Etos Kerja Terhadap Produktivitas Kerja Pegawai Pada Kantor Balai Benih Ikan (BBI) Pengujan
}

\author{
Delfi Wirayani, Lia Suprihartini, Roni Kurniawan \\ Fakultas Ekonomi Universitas Maritim Raja Ali Haji, Tanjungpinang, Kepulauan Riau, Indonesia
}

\begin{abstract}
ABSTRAK : Penelitian ini membahas tentang peran penyuluh dan bagaimana strategi pemasaran yang diduga mempengaruhi volume penjualan kelompok nelayan desa Madong Tanjungpinang. Dalam penelitian ini variable peran penyuluh dilihat dari indikator kinerja dan kompetensi; strategi pemasaran dilihat dari indikator market segmentasi, market positioning, market entry strategi, marketing mix; serta volume penjualan dari indikator Laba dan Penjualan. Penelitian ini menggunakan aplikasi program SPSS.V.24, meunjukkan bahwa secara parsial Strategi Penjualan berpengaruh secara positif dan signifikan terhadap Volume Penjualan dan Peran Penyuluh berpengaruh secara secara positif dan signifikan terhadap Volume Penjualan. Secara simultan Peran Penyuluh dan Strategi Penjualan berpengaruh positif dan signifikan terhadap Volume Penjualan.
\end{abstract}

Kata Kunci : Peran Penyuluh, Strategi Pemasaran, Volume Penjualan

ABSTRACT : This study discusses the role of extension agents and how marketing strategies are thought to affect the sales volume of the fishermen group in Tanjung Pinang village. In this study the role of instructor variables is seen from performance and competency indicators; marketing strategy seen from indicators of market segmentation, market positioning, market entry strategy, marketing mix; and sales volume of profit and sales indicators. This study uses the SPSS.V.24 program application, showing that partially the Sales Strategy has a positive and significant effect on Sales Volume and the Extension Role has a positive and significant effect on Sales Volume. Simultaneously the Extension Role and Sales Strategy have a positive and significant effect on Sales Volume

Keywords: Extension Role, Marketing Strategy, Sales Volume

Email Address : delfiwirayani@gmail.com 


\section{Pendahuluan}

Sumber Daya Manusia (SDM) dalam suatu sistem organisasi merupakan salah satu modal dasar dalam suatu perusahaan, sumber daya manusia memegang peran yang sangat penting dalam mencapai tujuan perusahaan/instansi. Oleh karena itu perusahaan/instansi perlu mengelolah dan mengembangkan SDM dengan baik. Perusahaan/instansi yang mempunyai pandangan untuk maju terlihat dari sumber daya manusia yang benar-benar berdaya guna untuk perusahaan/instansi. Untuk mencapai tujuan perusahaan/organisasi diperlukan suatu sikap kedisiplinan kerja pegawai dari masingmasing pegawai tersebut dapat ditingkatkan, yang mana pada gilirannya produktivitas kerja pegawai secara keseluruhan akan meningkat pula.

Pengalaman kerja adalah pengetahuan atau keterampilan yang sudah diketahui dan dikuasai seseorang sebagai akibat perbuatan atau pekerjaan yang telah dilakukan sebelumnya selama jangka waktu tertentu. Pegawai yang memiliki pengalaman lebih banyak akan mempunyai tingkat kepuasan kerja yang lebih tinggi dengan adanya pengalaman kerja akan membuat pegawai lebih berhati-hati serta belajar dari kesalahankesalahan sehingga dalam menyelesaikan suatu pekerjaan akan terasa lebih memuaskan. Pegawai yang kepuasan kerjanya terpenuhi akan bekerja secara maksimal sehingga pegawai tersebut dapat memenuhi target atau tujuan yang telah disepakati. Begitupun sebaliknya jika kepuasan kerja pegawai tidak terpenuhi maka pegawai tidak akan bekerja secara maksimal dan produktivitas pegawai tersebut menurun. Sumber daya manusia yang berkualitas juga dapat dilihat dari etos kerja pegawai yang maksimal. Semakin tinggi etos kerja pegawai maka kualitas pegawai akan semakin baik.

\section{Tujuan Penelitian}

Dari uraian permasalahan diatas, adapun yang menjadi tujuan dari penelitian ini yaitu :

1. Untuk mengetahui pengaruh Disiplin Kerja terhadap produktivitas kerja pada Kantor Balai Benih Ikan (BBI) Pengujan

2. Untuk mengetahui pengaruh Pengalaman Kerja terhadap produktivitas kerja pada Kantor Balai Benih Ikan (BBI) Pengujan

3. Untuk mengetahui pengaruh Kepuasan Kerja terhadap produktivitas kerja pada pada Kantor Balai Benih Ikan (BBI) Pengujan

4. Untuk mengetahui pengaruh Etos Kerja terhadap produktivitas kerja pada pada Kantor Balai Benih Ikan (BBI) Pengujan

5. Untuk mengetahui pengaruh Disiplin Kerja, Pengalaman kerja, Kepuasan kerja dan Etos Kerja secara bersama-sama terhadap produktivitas kerja pada pada Kantor Balai Benih Ikan (BBI) Pengujan

\section{Pembahasan \\ Produktivitas Kerja}

Mulyana (2010 : 23) Produktivitas adalah hasil kerja nyata atau produk yang dihasilkan seseorang dalam melakukan aktivitas atau pekerjaan dalam kurun waktu tertentu dan dapat digunakan sebagai tolak ukur kualitas kerja seseorang. Menurut Sutrisno (2013 : 99) produktivitas adalah hubungan antara keluaran (barang atau jasa) dengan masukan (tenaga kerja, bahan, uang).

\section{Indikator Produktivitas}

Adapun indikator produktivitas menurut Sutrisno (2013: 104) yaitu :
1. Kemampuan
2. Meningkatkan hasil yang dicapai
3. Semangat Kerja
4. Pengembangan Diri
5. Mutu
6. Efisiensi

\section{Disiplin Kerja}

Menurut Hasibuan (2010 : 193) disiplin adalah kesadaran seseorang menaati semua 
peraturan perusahaan dan norma-norma sosial yang berlaku. Untuk mencapai hasil yang baik dan sesuai tujuan, perlu adanya disiplin kerja dari personel yang bersangkutan. Menurut Siagian (2012 : 305) disiplin adalah tindakan manajemen untuk mendorong para anggota organisasi memenuhi tuntutan berbagai ketentuan. Sikap disiplin kerja yang dimiliki oleh pegawai sangat penting bagi suatu perusahaan/instansi dalam rangka mewujudkan tujuan perusahan/instansi serta dapat meningkatkan efektivitas dan efesiensi kerja pegawai.

\section{Indikator Disiplin Kerja}

Menurut Hasibuan (2006) indikator disiplin kerja yaitu :
1. Sikap
2. Norma
3. Tanggung Jawab

\section{Pengalaman Kerja}

Handoko (2009 : 27) menyatakan bahwa Pengalaman kerja seseorang menunjukkan jenis-jenis pekerjaan yang telah dilakukan seseorang yang memberikan peluang besar bagi seseorang untuk melakukan pekerjaan yang lebih baik selama jangka waktu tertentu. Menurut Sulaeman (2014 : 97) Karyawan yang mempunyai pengalaman yang lebih lama akan mempunyai keterampilan yang lebih tinggi, sehingga produktivitasnya pun lebih tinggi dibandingkan tenaga kerja yang baru memiliki sedikit pengalaman.

\section{Indikator Pengalaman Kerja}

Ada beberapa hal juga untuk menentukan berpengalaman tidaknya seseorang karyawan yang sekaligus sebagai indikator pengalaman kerja menurut (Foster, 2001 : 43) yaitu :

1. Lama waktu atau masa kerja.

2. Tingkat pengetahuan dan keterampilan yang dimiliki.

3. Penguasaan terhadap pekerjaan atau peralatan.

\section{Kepuasan Kerja}

Menurut George dan Jones (2014 : 291) Kepuasan kerja adalah merupakan sekumpulan perasaan, keyakinan, dan pikiran tentang bagaimana respon seseorang terhadap pekerjaannya. Menurut Ardana (2012 : 147) kepuasan kerja adalah suatu cara pandang seseorang, baik yang bersifat positif maupun negatif tentang pekerjaannya.

\section{Indikator Kepuasan Kerja}

Menurut Soedjono (2005 : 27) terdapat lima indikator yang dapat dijadikan pengukuran kepuasan kerja. Indikator tersebut yaitu :

1. Kepuasan pada pekerjaan itu sendiri

2. Kepuasan pada pembayaran

3. Kepuasan tentang promosi

4. Kepuasan pada supervisi

5. Kepuasan pada rekan kerja

\section{Etos Kerja}

Harsono \& Santoso (2006) menyatakan bahwa etos kerja adalah semangat kerja yang didasari oleh nilai-nilai atau norma-norma tertentu. Sedangkan Menurut Chaplin (2011) mengatakan bahwa etos kerja adalah watak atau karakter suatu kelompok nasional atau kelompok rasial tertentu. Etos kerja dalam suatu perusahaan tidak akan muncul begitu saja, akan tetapi harus diupayakan dengan sungguh-sungguh melalui proses yang terkendali dengan melibatkan semua sumber daya manusia dalam seperangkat sistem dan alat-alat pendukung yang ada dalam perusahaan tersebut.

\section{Indikator Etos Kerja}

Miller dan Whoer (2001) Merumuskan indikator etos kerja yaitu :

1. Kemandirian

2. Moralitas

3. Waktu Luang

4. Kerja keras

5. Sentralisasi dalam bekerja

6. Waktu yang terbuang

7. Penundaan kepuasan 


\section{Metode Penelitian}

Adapun yang menjadi objek dalam penelitian ini adalah pada Kantor Balai Benih Ikan (BBI) Pengujan Penelitian ini dimulai dari bulan Oktober 2017. Jenis penelitian ini adalah penelitian kuantitatif. Menurut Sugiyono (2015 : 35) kuantitatif adalah metode penelitian yang berlandasan pada filsasaf positivisme yang digunakan untuk meneliti populasi atau sampel tertentu, pengumpulan data dengan menggunakan instrumen penelitian, analisis data bersifat kuantitatif/statistik, dengan tujuan untuk menguji hipotesis yang telah ditetapkan. Teknik pengambilan sampel yang digunakan adalah teknik nonprobability sampling dengan menggunakan teknik sampel jenuh. Populasi yang digunakan yaitu sebanyak 32 pegawai pada Kantor Balai Benih Ikan (BBI) Pengujan. Sampel yang digunakan yaitu teknik sampel jenuh yang berarti seluruh populasi dijadikan sampel. Metode analisis data yang digunakan yaitu pengeditan, pemberian skor dan tabulasi. Uji hipotesis dilakukan baik secara parsial maupun secara simutan.

\section{Hasil dan Pembahasan}

\section{Hasil uji statistik deskriptif}

Tabel 4.12

Hasil Uji Statistik Deskriptif

Descriptive Statistics

\begin{tabular}{|l|r|r|r|r|r|}
\hline & N & Min & Max & Mean & Std. Deviation \\
\hline DISIPLIN & 32 & 32 & 45 & 40,62 & 3,434 \\
PENGALAMAN_KERJ & 32 & 11 & 20 & 16,75 & 2,369 \\
A & 32 & 28 & 40 & 35,34 & 4,323 \\
KEPUASAN_KERJA & 32 & 24 & 40 & 36,53 & 3,282 \\
ETOS_KERJA & 32 & 24 & 40 & 35,78 & 4,309 \\
PRODUKTIVITAS_KE & 32 & & & & \\
RJA & & & & \\
Valid N (listwise) &
\end{tabular}

(Sumber : Hasil Pengolahan Data Kuesioner 2018)

Pada tabel 4.12 menjelaskan bahwa pada variabel disiplin kerja jawaban minimum responden sebesar 32 dan maksimum sebesar 45 dengan rata-rata total jawaban 40,62 dan standar deviasi 3,434. Variabel pengalaman kerja jawaban minimum sebesar 11 dan maksimum 20 dengan rata-rata total jawaban 16,75 dan standar deviasi sebesar 2,369. Variabel kepuasan kerja jawaban minimum

\section{Hasil Uji Asumsi Klasik Hasil Uji Normalitas}

sebesar 28 dan maksimum 40 dengan rata-rata total jawaban 35,34 dan standar deviasi sebesar 4,323. Variabel etos kerja jawaban minimum sebesar 24 dan maksimum 40 dengan rata-rata total jawaban 36,53 dan standar deviasi sebesar 3,282 . Variabel produktivitas kerja jawaban minimum sebesar 24 dan maksimum 40 dengan rata-rata total jawaban 35,78 dan standar deviasi sebesar 4,309.

Uji normalitas bertujuan untuk menguji apakah dalam model regresi variabel terikat 
dan variabel bebas keduanya mempunyai dapat dilihat pada gambar berikut ini : distribusi normal atau tidak. grafik P-Plot

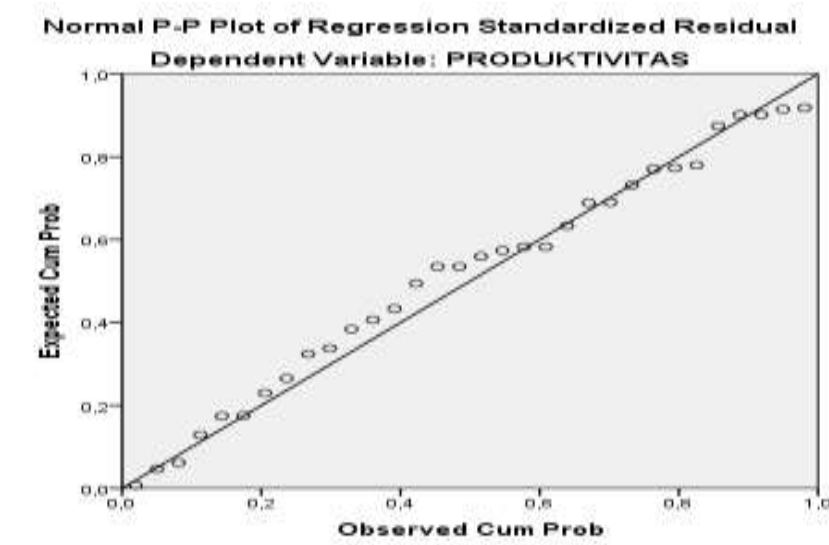

(Sumber : Hasil Pengolahan Data Kuesioner 2018)

Gambar 4.3

Hasil Grafik P-Plot

Gambar 4.3 diperoleh hasil bahwa semua data berdistribusi secara normal. Karena sebaran data berada sekitar garis diagonal dan mengikuti arah garis diagonal.

\section{Hasil Uji Multikolinearitas}

Uji multikolinearitas dilakukan dengan menggunakan nilai variance Inflation Factor
(VIF) dengan tolerance.suatu model dikatakan bebas dari multikolinearitas apabila nilai VIF yang kurang dari 10 dan nilai tolerance lebih dari 0,10 . Hasil dari pengujian multikolinearitas dapat dlihat pada tabel berikut ini.

Tabel 4.24

Hasil Uji Multikolinearitas

Coefficients a

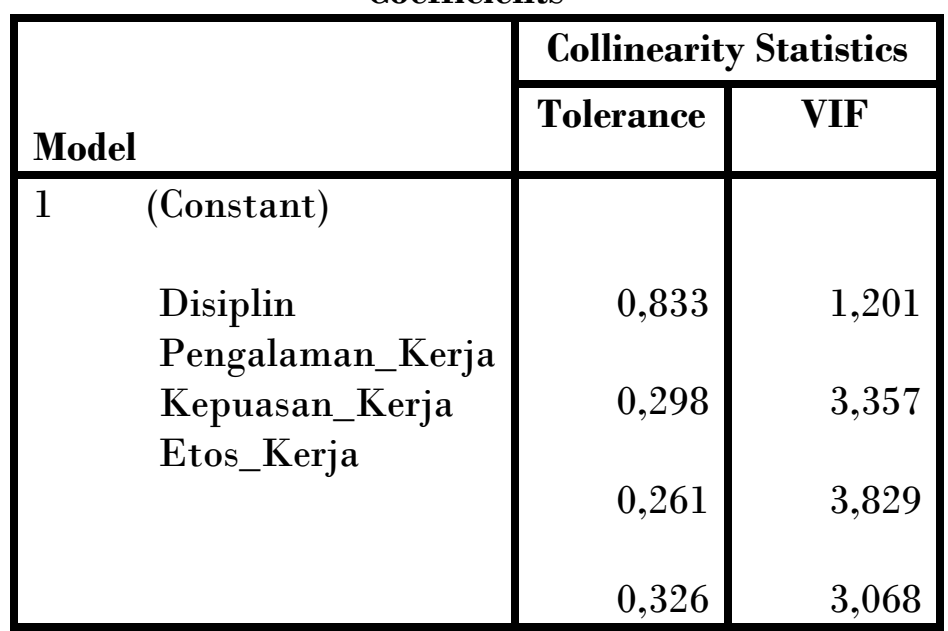

a. Dependent Variable : Produktivitas

(Sumber : Hasil Pengolahan Data Kuesioner 2018) 
Dapat dilihat hasil perhitungan
menunjukkan nilai tolerance variabel independen memiliki nilai tolerance $>0,10$ dan hasil perhitungan nilai VIF juga menunjukkan Variabel independen memiliki nilai $\mathrm{VIF}<10$. Dapat disimpulkan tidak terjadi multikolinearitas antar variabel independen dalam model regresi.

\section{Hasil Uji Heteroskedastisitas}

Uji heteroskedastisitas digunakan untuk mengetahui ada atau tidaknya ketidaksamaan varian dari residual atau pengamatan ke pengamatan yang lain. Prasyarat dalam model regresi adalah tidak terjadinya heteroskedastisitas. Cara untuk mendeteksi ada atau tidaknya heteroskedastisitas dapat dilihat meggunakan grafik scatterplot yaitu seperti pada gambar berikut ini :

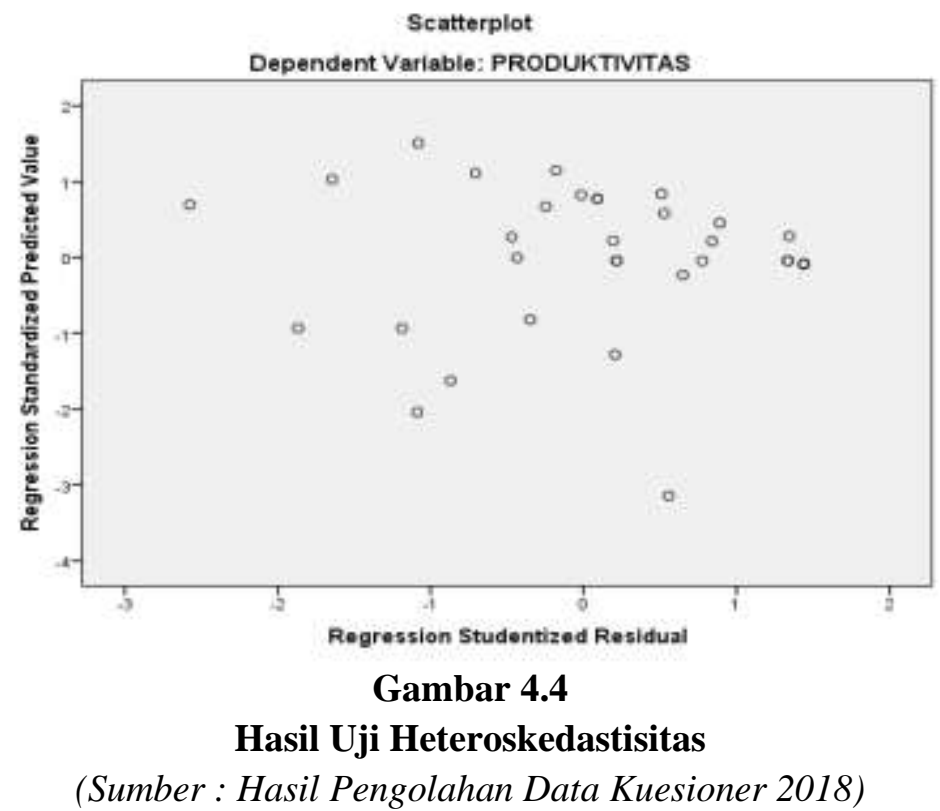

Dari grafik scatterplot diatas terlihat bahwa titik-titik menyebar secara acak serta tersebar baik diatas maupun dibawah angka 0 pada sumbu Y. Hal ini dapat disimpulkan bahwa tidak terjadi heteroskedastisitas pada regresi, sehingga model regresi layak dipakai untuk memprediksi produktivitas berdasarkan masukan variabel independen disiplin kerja, pengalaman kerja, kepuasan kerja dan etos kerja.

\section{Pengujian Analisis Regresi Linear Berganda}

Analisi regresi linear berganda digunakan untuk mengetahui pengaruh variabel independen terhadap variabel dependen. Hasil uji regresi linear berganda pada penelitian ini dapat dilihat pada tabel berikut ini : 
Tabel 4.25

Hasil Uji Analisis Regresi Linear Berganda

Coefficients a

\begin{tabular}{|c|c|c|c|c|c|}
\hline \multirow[b]{2}{*}{ Model } & \multicolumn{2}{|c|}{$\begin{array}{c}\text { Unstandardized } \\
\text { Coefficient }\end{array}$} & \multirow{2}{*}{$\frac{\begin{array}{c}\text { Standardized } \\
\text { Coefficient }\end{array}}{\text { Beta }}$} & \multirow[b]{2}{*}{$\mathrm{t}$} & \multirow[b]{2}{*}{ Sig. } \\
\hline & B & $\begin{array}{l}\text { Std.Err } \\
\text { or }\end{array}$ & & & \\
\hline (Constant) &, 323 & 4.973 & &, 065 & ,949 \\
\hline DISIPLIN &,- 189 & , 106 &,- 150 & $-1,782$ & ,086 \\
\hline PENGALAMAN &, 251 & ,257 & ,138 &, 979 & ,336 \\
\hline KEPUASAN & , 145 & , 150 & ,148 &, 967 &, 342 \\
\hline ETOS_KERJA &, 925 & 177 &, 704 & 5,220 &, 000 \\
\hline
\end{tabular}

Dependent Variable: PRODUKTIVITAS

(Sumber : Hasil Pengolahan Data Kuesioner 2018)

Berdasarkan tabel diatas dapat disusun persamaan regresi linear berganda dan diimplementasikan sebagai berikut :

PRODUKTIVITAS $=0,323-0,189$ DISIPLIN $+0,251$ PENGALAMAN + 0,145

KEPUASAN + 0,925 ETOS_KERJA + e

Nilai konstanta $(\mathrm{a})=0,323$, artinya jika nilai variabel disiplin kerja, pengalaman kerja, kepuasan kerja dan etos kerja dianggap tidak ada atau sama dengan 0 , maka nilai produktivitas kerja pegawai pada Kantor Balai Benih Ikan (BBI) Pengujan sama dengan 0,323 .

Nilai koefisien regresi disiplin kerja = 0,189 . Nilai disiplin kerja menunjukkan nilai negatif artinya jika nilai variabel disiplin kerja atau sama dengan nol, maka disiplin kerja akan semakin berkurang atau mengalami kenaikan nilai disiplin kerja negatif yaitu $-0,189$.

Nilai koefisien regresi pengalaman kerja $=$ 0,251 . Jika pengalaman kerja mengalami peningkatan 1 (satu) poin, maka pengalaman kerja akan mengalami peningkatan sebesar 0,251dengan asumsi bahwa variabel bebas lainnya tetap.

Nilai koefisien regresi kepuasaan kerja adalah sebesar 0,145. Jika kepuasan kerja mengalami peningkatan 1 (satu) poin, maka kepuasaan kerja akan mengalami peningkatan sebesar 0,145 dengan asumsi bahwa variabel bebas lainnya tetap.

Nilai koefisien regresi etos kerja adalah sebesar 0,925. Jika etos kerja mengalami peningkatan 1 (satu) poin, maka etos kerja akan mengalami peningkatan sebesar 0,925 dengan asumsi bahwa variabel bebas lainnya tetap. 


\section{Hasil Pengujian Hipotesis \\ Hasil Uji Signifikan Parsial (Uji t)}

Tabel 4.26

Hasil Uji Statistik T

\begin{tabular}{|c|c|c|c|c|c|}
\hline \multirow{2}{*}{ Model } & \multicolumn{2}{|c|}{$\begin{array}{c}\text { Unstandardized } \\
\text { Coefficient }\end{array}$} & \multirow{2}{*}{$\begin{array}{c}\begin{array}{c}\text { Standardiz } \\
\text { ed } \\
\text { Coefficient }\end{array} \\
\text { Beta }\end{array}$} & \multirow{2}{*}{$\mathrm{t}$} & \multirow{2}{*}{ Sig. } \\
\hline & B & Std.Error & & & \\
\hline (Constant) &, 323 & 4.973 & &, 065 & ,949 \\
\hline DISIPLIN &,- 189 & , 106 &,- 150 & $-1,782$ &, 086 \\
\hline PENGALAMAN & ,251 & ,257 & ,138 & ,979 & ,336 \\
\hline KEPUASAN & , 145 & , 150 & 148 & ,967 & ,342 \\
\hline ETOS_KERJA & ,925 & ,177 &, 704 & 5,220 &, 000 \\
\hline
\end{tabular}

Dependent Variable: PRODUKTIVITAS

(Sumber : Hasil Pengolahan Data Kuesioner 2018)

\section{Hipotesis 1 : Pengaruh Disiplin kerja terhadap produktivitas kerja}

Variabel disiplin kerja dengan nilai Sig 0,086 dan nilai thitung $-1,782$. Ini berarti Sig lebih besar dari taraf signifikasi $0,05(>0,05)$. Dan berdasarkan perbandingan thitung dan ttabel, didapat bahwa thitung $<\mathrm{t}$ tabel $(-1,782$ $<$ 1,70329). sehingga disiplin kerja secara parsial tidak berpengaruh signifikan terhadap produktivitas kerja. Hal ini sejalan dengan penelitian yang dilakukan Assagaf dan Dotulong (2015) yang menyatakan bahwa disiplin kerja secara parsial dan signifikan tidak berpengaruh terhadap produktivitas kerja. Serta hasil penelitian ini bertolak belakang dengan penelitian yang dilakukan oleh Ananta dan Adnyani (2016) yang menyatakan bahwa disiplin kerja secara parsial berpengaruh terhadap produktivitas kerja.

\section{Hipotesis 2 : Pengaruh Pengalaman Kerja Terhadap Produktivitas Kerja}

Variabel Pengalaman kerja dengan nilai Sig ,138 dan nilai thitung 0,979. Ini berarti sig lebih besar dari taraf signifikasi $0,05(>0,05)$.
Dan berdasarkan perbandingan thitung dan ttabel, didapat bahwa thitung < t tabel $(0,979<$ 1,70329). Maka dalam hal ini pengalaman kerja tidak berpengaruh signifikan terhadap produktivitas kerja. Hasil penelitian ini sejalan dengan penelitian yang dilakukan oleh Faris et al (2016) dan hasil penelitian ini bertolak belakang dengan penelitian yang dilakukan oleh Itafia et al (2014) yang menyatakan bahwa pengalaman kerja berpengaruh secara parsial terhadap produktivitas kerja.

\section{Hipotesis 3 : Pengaruh Kepuasan Kerja kerja Terhadap Produktivitas Kerja}

Variabel kepuasan kerja dengan nilai Sig 0,342 dan nilai thitung 0,967 . Ini berarti sig lebih besar dari taraf signifikasi 0,05 (>0,05). Dan berdasarkan perbandingan thitung dan ttabel, didapat bahwa thitung < ttabel $(0,967<$ 1,70329).Dalam hal ini kepuasan kerja tidak berpengaruh signifikan terhadap produktivitas kerja.

Hipotesis 4 : Pengaruh Etos Kerja kerja Terhadap Produktivitas Kerja 
Variabel etos kerja dengan nilai Sig 0,000 dan nilai thitung 5,220. Ini berarti sig lebih kecil dari taraf signifikasi $0,05(>0,05)$. Dan berdasarkan perbandingan thitung dan ttabel, didapat bahwa thitung < ttabel $(5,220<$ 1,70329).

Dalam hal ini etos kerja secara parsial berpengaruh signifikan terhadap produktivitas kerja. Hasil penelitian ini sejalan dengan penelitian yang dilakukan oleh Faderika (2016) yang menyatakan bahwa etos kerja secara parsial dan simultan berpengaruh terhadap produktivitas kerja

\section{Hasil Uji Statistik Simultan (Uji F)}

Menurut Ghozali (2013 : 98) Uji statistik F menunjukkan apakah semua variabel independen atau bebas yang dimasukkan dalam model mempunyai pengaruh secara bersama-sama terhadap variabel dependen/terikat. Hasil uji F dapat dilihat pada tabel berikut ini :

Tabel 4.27

Hasil Uji F ANOVAa

\begin{tabular}{|c|c|c|c|c|c|}
\hline Model & $\begin{array}{c}\text { Sum of } \\
\text { Squares }\end{array}$ & Df & $\begin{array}{c}\text { Mean } \\
\text { Square }\end{array}$ & F & Sig. \\
\hline 1 Regression & 483,249 & 4 & 120,812 & 35,371 &, $000^{\mathrm{b}}$ \\
Residual & 92,220 & 27 & 3,416 & & \\
Total & 575,469 & 31 & & & \\
\hline
\end{tabular}

a. Dependent Variable: PRODUKTIVITAS

b. Predictors: (Constant), ETOS_KERJA, DISIPLIN, PENGALAMAN_KERJA, KEPUASAN_KERJA

(Sumber : Hasil Pengolahan Data Kuesioner 2018)

Berdasarkan tabel diatas, maka dapat disimpulkan bahwa nilai signifikan 0,000 dan nilai Fhitung 35,371. Hal ini berarti Sig lebih kecil dari 0,05 $(0,000<0,05)$. Dan berdasarkan perbandingan Fhitung dengan $\mathrm{F}(\mathrm{F}$ tabel $\alpha=0,05, \mathrm{df}=\ldots)$ didapat Fhitung 35,371 lebih besar dari Ftabel yaitu 2,73 (35,371 > 2,75). Maka dalam hal ini H5 diterima dan H0 ditolak yang menunjukkan bahwa disiplin kerja, pengalaman kerja, kepuasan kerja, etos kerja berpengaruh secara simultan dan signifikan terhadap produktivitas kerja.

\section{Pengujian Koefisien Determinasi (F2)}

Menurut Ghozali (2013 : 97) koefisien determinasi (R2) pada intinya mengukur seberapa jauh kemampuan model dalam menerangkan variasi variabel dependen. Adapun hasil analisis koefisien determinasi dalam penelitian ini dapat dilihat pada tabel berikut ini :

Tabel 4.28

Hasil Analisis Koefisien Determinasi Model Summary ${ }^{b}$

\begin{tabular}{|c|c|c|c|c|}
\hline Model & $\mathrm{R}$ & R Square & $\begin{array}{c}\text { Adjusted R } \\
\text { Square }\end{array}$ & $\begin{array}{c}\text { Std. Error of } \\
\text { the Estimate }\end{array}$ \\
\hline 1 &, $916^{\mathrm{a}}$ &, 840 &, 816 & 1,848 \\
\hline
\end{tabular}

a. Predictors: (Constant), ETOS_KERJA, DISIPLIN, PENGALAMAN_KERJA, KEPUASAN_KERJA

b. Dependent Variable: PRODUKTIVITAS 


\section{(Sumber : Hasil Pengolahan Data Kuesioner 2018)}

Dari tabel diatas dapat dilihat bahwa angka $\mathrm{R}$ disebut koefisien korelasi antara variabel disiplin kerja, pengalaman kerja, kepuasan kerja, dan etos kerja dengan produktivitas kerja adalah 0,916. Ini artinya hubungan antara variabel disiplin kerja, pengalaman kerja, kepuasan kerja, dan etos kerja dengan produktivitas kerja adalah kuat (signifikan sebesar 91,6\%. Adjusted $\mathrm{R}^{2}$ dalam penelitian ini adalah 0,816 hal ini menunjukkan bahwa sebesar $81,6 \%$ produktivitas kerja pada Kantor Balai Benih Ikan (BBI) Pengujan di pengaruhi oleh disiplin kerja, pengalaman kerja, kepuasan kerja, dan etos kerja. Sedangkan sisanya sebesar $18,4 \%$ dipengaruhi oleh faktorfaktor yang tidak dimasukkan dalam penelitian ini.

\section{Kesimpulan \\ Kesimpulan}

Berdasarkan hasil penelitian dari pengaruh disiplin kerja, pengalaman kerja, kepuasan kerja dan etos kerja terhadap produktivitas kerja pegawai pada Kantor Balai Benih Ikan (BBI) Pengujan. Maka dapat diambil kesimpulan sebagai berikut :

1. Disiplin kerja secara parsial tidak berpengaruh terhadap produktivitas kerja pada Kantor Balai Benih Ikan (BBI) Pengujan.

2. Pengalaman kerja secara parsial tidak berpengaruh terhadap produktivita kerja pada Kantor Balai Benih Ikan (BBI) Pengujan.

3. Kepuasan kerja secara parsial tidak berpengaruh terhadap produktivitas kerja pada Kantor Balai Benih Ikan (BBI) Pengujan.

4. Etos kerja secara parsial berpengaruh dan signifikan terhadap produktivitas kerja pada
Kantor Balai Benih Ikan (BBI) Pengujan.

5. Disiplin kerja, pengalaman kerja, kepuasan kerja dan etos kerja secara simultan berpengaruh dan signifikan terhadap produktivitas kerja pada Kantor Balai Benih Ikan (BBI) Pengujan.

\section{Saran}

1. Diharapkan agar pegawai yang ada lebih memperhatikan disiplin kerja. Selain itu perlu dilakukan pengawasan terhadap kedisiplinan pegawai dalam peningkatan absensi kehadiran pegawai.

2. Diharapkan pimpinan lebih memperhatikan kompensasi yang diterima pegawai.

3. Diharapkan agar pimpinan untuk menambahkan Jumlah SDM Teknisi.

4. Diharapkan untuk meningkatkan dan memperbaiki sarana dan prasarana

\section{Daftar Pustaka}

Ardana. (2012). Manajemen Sumber Daya Manusia. Yogyakarta: Graha Ilmu.

George \& Jones. (2014). Understanding and managing Organizational Behavior $\left(4^{\text {th }}\right.$ ed.). New Jersey: Upper Saddle River.

Handoko. (2001). Manajemen Personalia dan Sumber Daya Manusia. Yogyakarta: BPFE.

Hasibuan. (2006). Manajemen Sumber Daya Manusia, cetakan ketujuh penerbit PT. Bumi Aksara, Jakarta. 
(2009). Manajemen Sumber Daya Manusia, cetakan ketujuh penerbit PT. Bumi Aksara, Jakarta.

(2010). Manajemen Sumber Daya manusia. Jakarta: PT. Bumi Aksara.

(2014). Manajemen Sumber Daya Manusia. Edisi Revisi. Jakarta: Bumi Aksara.

Ghozali. (2013). Aplikasi Analisis Multivariate Dengan Program IBM SPSS 21. Semarang: badan Penerbit.

Siagian. (2012). Manajemen Sumber Daya Manusia. Bandung: Bumi Aksara.

Sugiyono. (2015). Metode Penelitian Manajemen. Bandung: Alfabeta.

Sulaeman, Andika. (2014). Pengaruh Upah dan Pengalaman Kerja terhadap Produktivitas Karyawan Kerajinan Ukiran Kabupaten Subang: Jurnal Trikonomika Vol. 13, N0. 1, Juni 2014. ISSN 23557737.

Sutrisno. (2013). Manajemen Sumber Daya Manusia. Jakarta: Kencana.

Soedjono. (2005). Pengaruh Budaya Organisasi Terhadap Kinerja organisasi dan Kepuasan kerja Karyawan PadaTerminal penumpang Umum di Surabaya. Jurnal Manajemen dan
Kewirausahaan. Vol. 7 No. 1 Hal. 24-27.

Miller \& Whoer. (2001). Etos Kerja. Jurnal Perilaku Vokasional. 59, 139.

Mulyana, AZ. (2010). Rahasia Menjadi Guru Hebat. Jakarta: Grasindo. 